\title{
Priorities and Allocations Support for Energy: Keeping Energy Programs on Schedule
}

A Program Administered Jointly by United States Department of Energy and

United States Department of Commerce
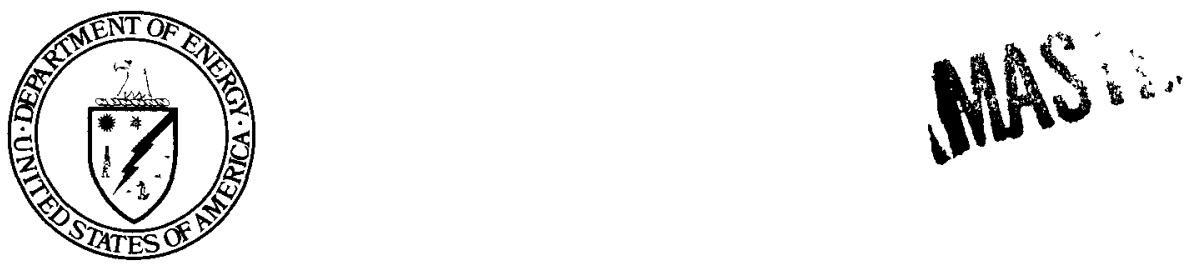

August 1985

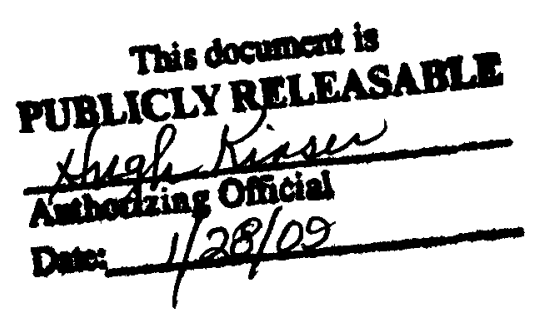

\section{U.S. Department of Energy}

Assistant Secretary, Management and Administration Procurement and Assistance Management Directorate Washington, D.C. 20585 


\section{DISCLAIMER}

This report was prepared as an account of work sponsored by an agency of the United States Government. Neither the United States Government nor any agency Thereof, nor any of their employees, makes any warranty, express or implied, or assumes any legal liability or responsibility for the accuracy, completeness, or usefulness of any information, apparatus, product, or process disclosed, or represents that its use would not infringe privately owned rights. Reference herein to any specific commercial product, process, or service by trade name, trademark, manufacturer, or otherwise does not necessarily constitute or imply its endorsement, recommendation, or favoring by the United States Government or any agency thereof. The views and opinions of authors expressed herein do not necessarily state or reflect those of the United States Government or any agency thereof. 


\section{DISCLAIMER}

Portions of this document may be illegible in electronic image products. Images are produced from the best available original document. 


\section{PREFACE}

This booklet describes priority and allocation support for certain energy programs and projects. Priorities and allocations for this purpose were provided for in PL 94-163, the Energy Policy and Conservation Act of 1975 which amended the Defense Production Act of 1950 , as amended. The amendment provided for the use of priorities and allocations for materials and equipment to support energy programs and projects. Previously, priorities and allocations were available only to national defense programs for military and atomic energy production or construction.

This booklet is not intended as a substitute for applicable rules and regulations of the Department of Energy and the Department of Commerce. Copies of this publication may be obtained from:

U.S. Department of Energy Office of Scientific and Technical Information P.O. Box 62

Oak Ridge, TN 37830 


\section{CONTENTS}

\section{Page}

Introduction

Application for Priorities and Allocations 2

A. Determination of Maximization of 3 Domestic Energy Supplies

B. Findings of Essentiality and Criticality of 4 Supplies of Materials and Equipment

C. Findings of Scarcity and Need to Use the System

Key Elements of the Defense Priorities and Allocations System (DPAS)
A. Rated Orders and Preferential Status
B. Priority Ratings
8
C. Set-Asides
D. Compliance and Enforcement Procedures
8
E. Benefits of the DPAS
9

Special Priorities Assistance 9

Conclusion

Form PR-437-Request for Priority Rating for Energy Programs 


\section{Introduction}

In order to assist persons experiencing difficulty in obtaining supplies of materials and equipment critical and essential to projects which will maximize domestic energy supplies, the Congress, through the Energy Policy and Conservation Act of 1975 (EPCA), included energy programs and projects under the priorities and allocations authority of the Defense Production Act of 1950(DPA), as amended. The Congress also has stated that these authorities are expected to be invoked where needed as authorized under the Energy Security Act of 1980 , provided the necessary findings are made. This handbook is designed to explain how priorities and allocations may be used to support such energy programs and projects.

The use of priorities and allocations for energy programs helps to ensure that energy projects which maximize domestic energy supplies are kept on schedule by providing priority treatment for the purchase of materials and equipment.

Section 104 of the EPCA amended the DPA by adding Section 101(c) to permit the President to require priority performance under contracts or orders, or the allocation of supplies of materials and equipment for programs or projects which maximize domestic energy supplies, if certain findings are made. Congress included this authority in the DPA so as not to create a priorities and allocations system that might conflict with existing priorities and allocations rules and regulations for national defense programs. Before authorizing priorities and allocations support for energy programs or projects, the President is required to find:

(a) that supplies of materials and equipment needed to maximize domestic energy supplies are scarce, critical, and essential to maintain or further (i) exploration, production, refining, transportation, or (ii) the conservation of energy supplies, or (iii) for the construction and maintenance of energy facilities; and

(b) that maintenance or furtherance of exploration, production, refining, transportation, or conservation of energy supplies or the construction and maintenance of energy facilities cannot reasonably be accomplished without exercising the authority.

Also, the statutory authority implies a determination that the program or project, in connection with the exercise of priorities and 
allocations authority, will "maximize domestic energy supplies."

Through Executive Order 11912, 44 CFR Part 330 (DMO-13) and a delegation of authority, the Department of Energy (DOE) and the Department of Commerce (DOC) make these findings.

In furtherance of their responsibilities under the priorities and allocations authority for energy programs and projects, both the DOE and the DOC have published regulations which establish and describe procedures to be used in implementing the authority.

The DOE regulations (10 CFR 216) establish the procedures and criteria used in deciding whether programs or projects maximize domestic energy supplies and whether supplies of materials and equipment are critical and essential, as contemplated by the DPA, Section 101(c). The Secretary of Energy has assigned the responsibility for administering DOE priorities and allocations authority to the Procurement and Assistance Management Directorate.

The DOC regulations (15 CFR 350, Subpart E) establish the procedures and criteria used in finding whether the supplies of materials and equipment are scarce and whether there is a need to use the priorities and allocations system. The Secretary of Commerce has assigned the responsibility for administering DOC priorities and allocations authority to the Office of Industrial Resource Administration.

\section{Application for Priorities and Allocations}

In processing applications for priorities and allocations, certain findings and determinations must be made before priority rating authorization can be granted. The DOE must 1) determine whether the energy program or project for which priorities and allocations authority is requested maximizes domestic energy supplies, and 2) find whether the materials and equipment are critical and essential to the program or project. The DOC must find 1) that the supplies of materials and equipment are scarce, and 2) that there is a need to use the priorities and allocations system.

Applicants requesting priorities and allocations authorization must file DOE form PR-437 (see page 12 ). The information requested on the form PR-437 will assist the DOE and the DOC in making their findings. Copies of the form may be obtained from the DOE Office of Scientific and Technical Information, P.O. Box 62, Oak Ridge, TN 37830. 
Completed applications should be forwarded to the:
U.S. Department of Energy
Procurement and Assistance
Management Directorate
ATTN: MA-422
1000 Independence Ave., SW
Washington, D.C. 20585

The following sections explain the processing of the application.

\section{A. Determination of Maximization of Domestic Energy Supplies}

The first step in processing the application is to determine if the program or project involved maximizes domestic energy supplies.

The DOE has established that the term "maximize domestic energy supplies" should include, but not be limited to, energy programs or projects which will contribute to the overall objective of improving our Nation's energy resource situation. This concept will include programs or projects which:

(1) increase quantities of domestic energy

(2) conserve and reduce the demand for energy, especially nonrenewable sources of energy

(3) convert to more abundant sources of energy

(4) promote decreased reliance on foreign sources of energy, or

(5) promote more efficient use of energy

The criteria used in determining whether an energy project or program maximizes domestic energy supplies include, but are not limited to, the following:

(1) The quantity of energy involved: The amount of energy produced by the program or project and quantity estimated to be lost or not produced if delays occur. An energy program or project producing or conserving substantial amounts of energy would be given more consideration than one which did not.

(2) Benefits of timely energy program or project completion: 
The amount of energy conserved or produced or the amount of imported energy saved by timely completion of the energy program or project.

(3) Impact: The impacts, if any, caused by delays in the timely completion of the energy program or project. For example, if there is a delay in the completion of a natural gas pipeline which would cause the closing of plants or critical local facilities, more favorable consideration would be given.

(4) Established national energy policies: For example, a program which will result in reduced dependence on foreign oil and a decrease in supply disruptions will be accorded more consideration for the granting of priority authority than an energy program or project which is not compatible with established national energy policy.

After the maximization determination has been made, the program or project will be referred to as "eligible." Whether the critical and essential findings are made does not affect the "eligible" status of the program or project. In subsequent applications involving the same project, no repeat determination of maximization is necessary. If a project is determined to be "eligible," it remains so until the DOE decides otherwise.

\section{B. Findings of Essentiality and Criticality of Supplies of Materials and Equipment}

After determining that an application for priorities and allocations authority relates to a program or project which maximizes domestic energy supplies, the DOE will then consider whether the material and equipment for which priorities and allocations authority is requested are essential and critical to the completion of the project or program.

In making the finding of essentiality, the basic consideration is whether the supplies of material and equipment are indispensible to the eligible program. The criteria for making this finding include:

(1) that the item is fundamental to the energy program or project, and

(2) that no substitute material is readily available. 
The finding of criticality concerns the urgency of obtaining the particular material and equipment.

Applications for programs or projects which are determined by the DOE to maximize domestic energy supplies and for which supplies of materials and equipment are found to be critical and essential will be forwarded to the DOC for further processing.

If, however, the DOE does not find that the materials and equipment are critical and essential, or does not determine that the energy program or project maximizes domestic energy supplies, the application will be considered denied. The DOE will promptly inform the applicant of its decision. The applicant may submit a petition for reconsideration to the U.S. Department of Energy, Procurement and Assistance Management Directorate, MA-422, 1000 Independence Avenue, S.W., Washington, D.C. 20585. The DOE will consider the petition and either grant or deny the requested relief. The applicant will then be notified of the decision and the reasons for it.

\section{Findings of Scarcity and Need to Use the System}

The DOC is responsible for finding 1) whether the supplies of materials and equipment are scarce, and 2) whether the program or project can reasonably be accomplished without exercising priorities and allocations authority.

Scarcity for the purpose of this finding implies unusual difficulty for the purchaser in obtaining the materials or equipment in appropriate specification, quality, quantity and in a time span consistent with the purposes of the eligible energy program or project. The finding of scarcity is, therefore, contingent on the extent to which the projected procurement pattern deviates (for whatever reason) from the delivery date(s) necessary for the timely completion of the project. Sources of supply considered for the purpose of the scarcity determination include all persons who are capable of meeting required product specifications, quality and quantity within the required time frame.

In considering whether the supplies of materials and equipment are scarce, DOC will consider all factors which it considers relevant, including the following: 
(1) shipments

(2) consumption

(3) imports and exports

(4) sources of supply

(5) inventories of producers, users and traders

(6) rates of capacity utilization

(7) volume of new orders

(8) average lead time for filling orders.

In making the finding of whether there is need to use the priorities and allocations system, the DOC will consider all factors which it considers relevant, including the following:

(1) alternative solutions to the supply problem, and

(2) to the extent practicable, an assessment of the effects of using the authority for the project in question on other significantly impacted projects.

If the DOC does not find both scarcity and a need to use the svstem, the DOC will return the application to the DOE who will then inform the applicant of the DOC decision. The applicant or the DOE may submit a request for reconsideration in triplicate to the Office of Industrial Resource Administration, Room 3876, U.S. Department of Commerce, 14th St. and Constitution Ave., NW, Washington, D.C. 20230 . The DOC will consider the petition and either grant or deny the request. Written notice of the decision and the reasons for it will be provided to the applicant and the DOE.

If the DOE and the DOC act favorably on the application, the DOC will assign a priority rating and program identification symbol and authorize the DOE to grant priority authority to the applicant to obtain specifically described materials or equipment. The DOE will authorize the applicant to apply the priority rating and program identification symbol to contracts or orders for specific materials or equipment. In using priority authority, the applicant is governed by the rules, regulations, and procedures of the Defense Priorities and Allocations System. 


\section{Key Elements of the Defense Priorities and Allocations System (DPAS)}

Under Title I authority of the DPA, DOC administers a system of rules, regulations, and procedures known as the Defense Priorities and Allocations System (DPAS). The DPAS regulation (15 CFR 350) sets forth U.S. industry's privileges and obligations in placing, accepting, and giving preferential treatment to contracts and purchase orders identified with an authorized priority rating.

Any person who receives an authorization to use a priority rating as a result of having filed form PR-437 is obligated to be aware and follow the provisions of the DPAS.

Copies of the regulation may be obtained from the:

Office of Industrial Resource Administration

U.S. Department of Commerce-Room 3876

14th St. and Constitution Ave., NW

Washington, D.C. 20230

Under the DPAS, there is no distinction between a contract or purchase order for an authorized national defense program or an eligible energy program-purchase orders for both types of programs have equal preferential status when properly identified with an authorized priority rating and other necessary elements of a rated order.

\section{A. Rated Orders and Preferential Status}

As provided by the DPAS rules and regulations, rated orders for industrial products, materials, and services have preferential status and take precedence over all unrated orders to ensure timely delivery and completion of authorized programs and projects. The DPAS also provides rules and procedures governing the priority rating of orders for the procurement of the controlled materials -steel, copper, aluminum, and nickel alloys. Generally, rated orders must be accepted if the required delivery date can be met, even if it means displacing existing unrated orders. 


\section{B. Priority Ratings}

Under the DPAS there are two priority ratings- "DO" and "DX." A complete priority rating consists of either of these rating symbols plus an appropriate program identification. The three program identification symbols for energy programs are:

F-1 To maintain or further domestic energy exploration, production, refining, and/or transportation

F-2 To maintain or further conservation of energy supplies

F-3 Construction and maintenance of energy facilities

Orders with ratings take precedence over unrated orders and $D X$ orders take precedence over DO orders. DX ratings are used only for programs of the highest national urgency as identified by the President. An important feature of the DPAS is the mandatory requirement that any person who receives a priority rating must extend the rating to each supplier in the industrial chain.

\section{Set-Asides}

One of the principal features of the DPAS is the current requirement that producers of copper, steel, aluminum, and nickel alloys "set-aside," or reserve, a portion of their products for national defense and energy programs. This assures the fullest possible support to the authorized programs. Set-asides can be established for any industrial resource.

\section{Compliance and Enforcement Procedures}

In the instance of a willful violation of the DPAS regulations, the Government has the authority to institute criminal proceedings. Maximum penalties are a $\$ 10,000.00$ fine, or a year in prison, or both. 


\section{E. Benefits of the DPAS}

Although following the provisions of the DPAS is a legal requirement incurred by all who receive rated orders, it also makes good business sense to be fully familiar with the system. For example, because vendors who receive rated orders are required to provide production materials on a prefential basis, a greater assurance exists of obtaining materials-even in times of scarcity; there is less liklihood of having orders bumped by other rated orders; the greater assurance of receiving production materials can be an important factor in developing competitive bids for rated contracts; and the necessity of maintaining large, costly inventories can be reduced, as inventories used to fill rated orders can be replaced with the use of ratings.

\section{Special Priorities Assistance}

After an applicant has been authorized to use a priority rating, and has properly extended that rating to all necessary suppliers, there should be no problem for the timely delivery of the items ordered. However, there are occasions when the regular DPAS procedures are not sufficient to obtain timely deliveries of required materials after rated contracts and purchase orders have been placed. This may result from a number of reasons including conflicting rated orders or inability to locate a supplier able to fill the order. The Special Priorities Assistance Program is designed to resolve these problems.

Special priorities assistance is used only after the DOE and the DOC have made the necessary findings and determinations and issued a rating to the contractor. However, special priorities assistance may be made available, as determined by the DOC, at the same time priority rating authority is authorized to the applicant. If the applicant finds that after having placed a rated order, the required delivery date will not be met by the supplier in order to permit meeting the required schedule, or if the applicant is unable to obtain acceptance of orders for required materials and equipment, the applicant must follow the procedures described below and in the DPAS.

The applicant must apply for special priorities assistance on a standard DOC application known as Form ITA-999, which can be obtained from the DOC or DOE. The application must contain information which substantiates that: 
(1) there is an urgent need for the material or service,

(2) the applicant has exhausted every means to resolve the problem,

(3) the request for assistance is timely, and

(4) the request is not seeking to:

a. force the solution of purely technical problems,

b. obtain price advantage,

c. force the resolution of contractual problems,

d. force unnecessary acceleration of delivery dates,

e. secure performance beyond the reasonable capability of the supplier, and

f. force acceptance of superior terms and conditions of sale.

Form ITA-999 is to be sent by the applicant to the U.S. Department of Energy, Procurement and Assistance Management Directorate, MA-422, 1000 Independence Ave., SW, Washington, D.C. 20585. The DOE will review the application, sign and foward it to the DOC only if the DOE cannot resolve the problem. The DOC may then try to locate an alternate supplier of the required materials or correct the problem in any other way necessary by dealing directly with the customer, the supplier, and the DOE.

In resolving these requests for special priorities assistance, the DOC might use one of several methods such as:

(1) arrangement of improved delivery dates by informal agreement with the suppliers, or

(2) issuance of a directive requiring the supplier to produce or deliver a specific item by a specified date.

A directive, which can be issued only by the $\mathrm{DOC}$, takes precedence over all rated orders. An example of directive action would be the rescheduling of the production and deliveries of a supplier to meet the needs of a particular energy program or project. 


\section{Conclusion}

This publication has covered DOE and DOC procedures related to an application for rating authority for an energy program, the DPAS, and the Special Priorities Assistance Program is relation to priorities and allocations for energy programs. A person engaged in an eligible energy program or project must be familiar with DPAS rules, regulations and procedures. There are important benefits to be gained by the Government and the energy industry through the proper use of the priorities and allocations system. 


\section{REQUEST FOR PRIORITY RATING FOR ENERGY PROGRAMS}

This form is authorized under the Defense Production Act of 1950 as amended by the Energy Policy and Conservation Act of 1975 PL 94163 Nopriority rating mav be authorized unless a completed application has been received information submitted on this form will be held confidential pursuant to the Defense Production Act of 1950 as amended and E O 10480

PLEASE READ THE INSTRUCTIONS ON PAGE 4 BEFORE COMPLETING

THIS FORM Use the continuation space on $p 4$ if needed

\section{IDENTIFICATION}

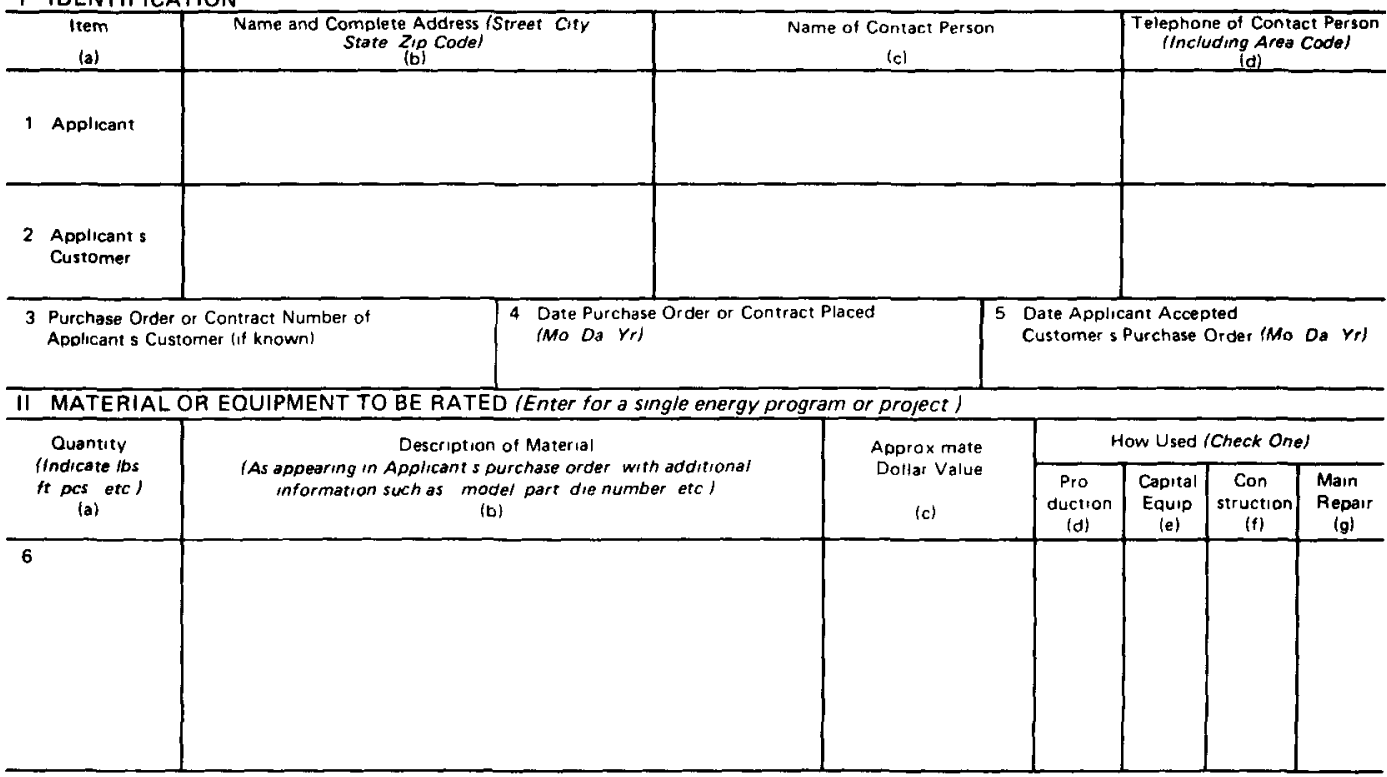

7 Describe the energy program or project to wh ch this application relates Inciude the type and location of the project the relationship to national or state energy programs or regulations etc 


\begin{tabular}{|c|c|c|c|c|}
\hline & & & & \\
\hline 9 & $\begin{array}{l}\text { Indicate the quantity of energy involved in the program or project descrit } \\
\text { explanation of methodology Complete each item as appropriate }\end{array}$ & ped in item 7 Provide & y supportin & d appropriate \\
\hline & $\begin{array}{l}\text { Question } \\
\text { (a) }\end{array}$ & $\left|\begin{array}{c}\text { Fues Converted To } \\
\text { (b) }\end{array}\right|$ & $\begin{array}{l}\text { Quantity } \\
\text { (c) }\end{array}$ & $\begin{array}{l}\text { Unit of Measure } \\
\text { (d) }\end{array}$ \\
\hline (1) & $\begin{array}{l}\text { If the necessary materisl is avalable, how much additional energy will be } \\
\text { produced per month? }\end{array}$ & & & \\
\hline (2) & $\begin{array}{l}\text { How much energy will be saved per month by the instaliation or use of } \\
\text { the necessary material? }\end{array}$ & & & \\
\hline (3) & $\begin{array}{l}\text { If the project will result in the conversion from petroleum fuel, what is } \\
\text { the fuel converted to and quantity of energy produced? }\end{array}$ & & & \\
\hline
\end{tabular}

10 in the event of a delayed receipt of the material or equpment in item 6 , indicate the resulting setback in project completion

\section{Amount of Delay}

(a)
Days

(b)

(1) If delayed up to 60 days project completion would be set back

(2) If delayed 60-90 days, project completion would be set back

(3) If delaved over 90 deys, project completion would be set back

11 Describe the social and/or economic impacts if any, attributable to the delays in the scheduled completion of the project Include, for example,

loss of jobs, environmental impact, energy curtailments etc

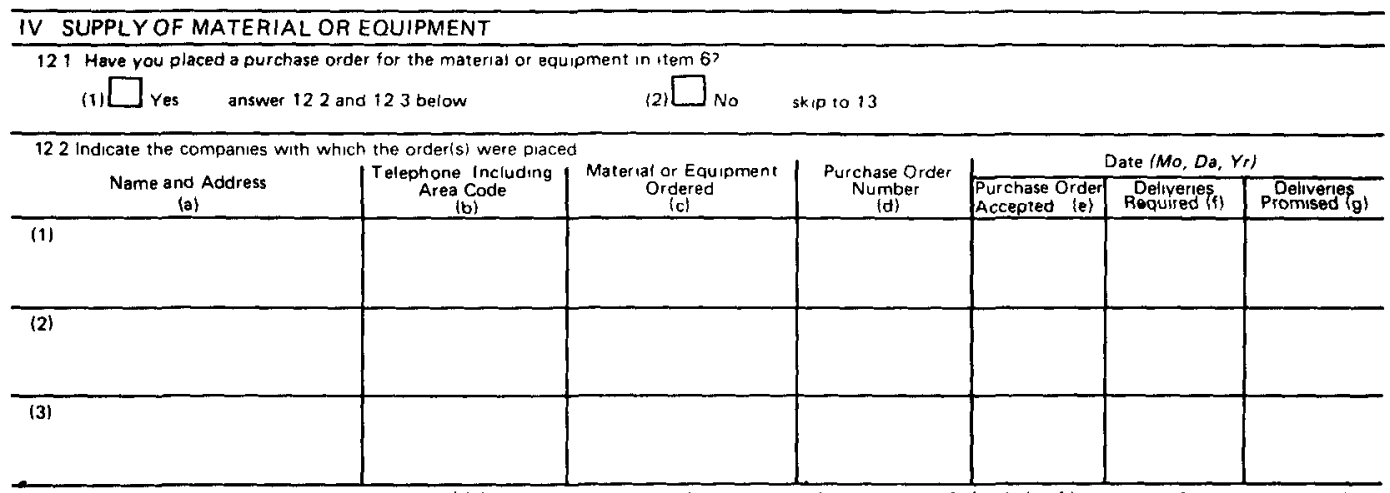

123 What were the reasons given by the supplier(s) for inability to meet applicant s required shipment date? (inc/ude, if known, interfering priority rated orders or programs ) 


\begin{tabular}{|c|c|c|}
\hline $\begin{array}{l}\text { Oote Contacted } \\
\text { (Mo, De, Yr) } \\
\end{array}$ & $\begin{array}{l}\text { Name and Complete Address } \\
\qquad \text { (b) }\end{array}$ & $\begin{array}{l}\text { Best Quoted Shrpment Date(s) and Other Pertinent Dats } \\
\qquad \text { (c) }\end{array}$ \\
\hline (1) & & \\
\hline (2) & & \\
\hline
\end{tabular}

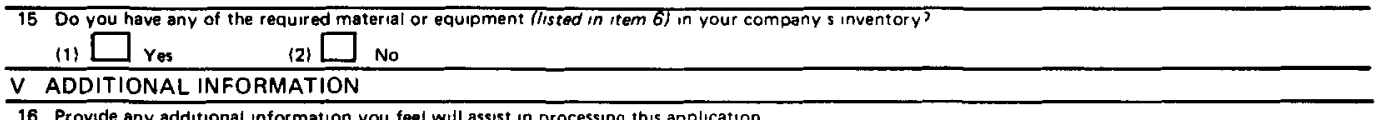

16 Provide any additional information you foel will assist in processing this application

\section{CERTIFICATION}

The undersigned Applicant and the official execuing this certification on its behalf, hereby certify that the information contained in items (1) to (16) inclusive of this form, as supplemented by any information at tached hereto and similarly signed is correct and complete to the best of their knowledge ond belief

\begin{tabular}{|c|c|c|c|}
\hline 17 & Name of Authorized Officiat & 18 Titie of Authorized Official & 19 Signature of Authorized Official \\
\hline 20 & Name of Applicent & & 21 Date Signed $\left(M o O \partial, Y_{r}\right)$ \\
\hline
\end{tabular}




\section{INSTRUCTIONS FOR FILING FORM PR 437}

(Note No priority ratıng or allocation may be authorized unless a completed form PR 437 has been received) GENERAL INFORMATION

1 Purpose

Form PR 437 provides a procedure for umplementing Department of Energy funcisons with regard to the allocation of or the pri ority performance under contracts or orders relating to supplies of materials and equipment in order to maximize domestic energy supplies

Refer to the U S Department of Energy (DOE) publication Priorities and Allocations Support for Energy Keeping Energy Programs on Schedule as a source of exblanation for the program Copies may be obtained from

\section{U S Department of Energy}

Office of Scientific and Technical Information

PO Box 62

Oak Ridge TN 37830

II Criteria for Priority Rating Authorization

Requests for Priority ratıng authorization must establish that the

1) Energy project or program involved is essential to maintain or further exploration production refining transportation or conservation of energy supplies or for the construction and maintenance of energy facilities

2) Supplies of materials and equipment are scarce critical and essential to the energv program or project

3) Energy program or project cannot reasonably be accom plished without authorizing the use of priorities and alloca tions

III Who May Apply

Any person may apply for priority ratıng or allocation assistance if such person is unable to obtain supplies of material or equip ment in order to maximize domestic energy supplies

IV When To Apply

File the PR 437 when there is difficulty or inability to obtain supplies of materials or equipment in order to maximize domestic energy supplies $\checkmark$ What To Submit

Submit an original and five (5) coptes of form PR 437

V) Where To Apply

Submit the form PR 437 to

U S Department of Energy

Procurement and Assistance

Management Directorate

MA-422

1000 Independence Ave, S W

Washington DC 20585

\section{GENERAL INSTRUCTION}

If the space in any item is insufficient for a clear and complete state ment of the information called for use the continuation space pro vided below or a separate sheet attached to the form identify as the item number contınued

\section{DEFINITIONS}

(As defined by 10CFR Part 216 Materials Allocation and Priority Performance Under Contracts or Orders to Maximize Domestic Energy Supplies ।

1 Materlals and equipment - Any raw in process or manufac tured commodity equipment component accessory part assem bly or product of any $k ı n d$

11 Appicant A person requesting priorities or aflocation assist ance in connection with an energy program or project

III Person An individual co poration partnership association or any other organized group of persons (or legal successor or representative thereof) and includes the United States or any other government and any political subdivisions (or any agency) thereof

\section{SPECIFIC INSTRUCTIONS}

Reter to the form All tems are self explanatory 